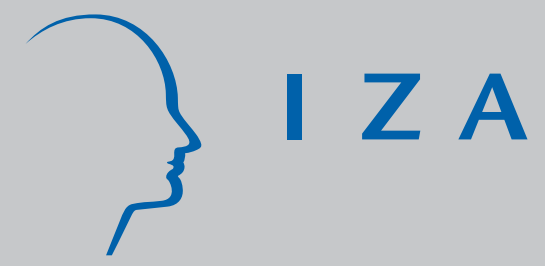

IZA DP No. 4806

Anticipation, Free-Rider Problem, and Adaptation to Trade Union: Re-examining the Curious Case of Dissatisfied Union Members

Nattavudh Powdthavee

March 2010 


\title{
Anticipation, Free-Rider Problem, and Adaptation to Trade Union: Re-examining the Curious Case of Dissatisfied Union Members
}

\author{
Nattavudh Powdthavee \\ University of York \\ and IZA
}

Discussion Paper No. 4806

March 2010

IZA

P.O. Box 7240

53072 Bonn

Germany

Phone: +49-228-3894-0

Fax: +49-228-3894-180

E-mail: iza@iza.org

\begin{abstract}
Any opinions expressed here are those of the author(s) and not those of IZA. Research published in this series may include views on policy, but the institute itself takes no institutional policy positions.

The Institute for the Study of Labor (IZA) in Bonn is a local and virtual international research center and a place of communication between science, politics and business. IZA is an independent nonprofit organization supported by Deutsche Post Foundation. The center is associated with the University of Bonn and offers a stimulating research environment through its international network, workshops and conferences, data service, project support, research visits and doctoral program. IZA engages in (i) original and internationally competitive research in all fields of labor economics, (ii) development of policy concepts, and (iii) dissemination of research results and concepts to the interested public.
\end{abstract}

IZA Discussion Papers often represent preliminary work and are circulated to encourage discussion. Citation of such a paper should account for its provisional character. A revised version may be available directly from the author. 
IZA Discussion Paper No. 4806

March 2010

\section{ABSTRACT}

\section{Anticipation, Free-Rider Problem, and Adaptation to Trade Union: Re-examining the Curious Case of Dissatisfied Union Members}

This paper documents evidence that rejects the paradox of dissatisfied union members. Using eleven waves of the BHPS, it studies the past, contemporaneous, and future effects of union membership on job satisfaction. By separating union "free-riders" from other nonmembers in the fixed effects equations, I find significant anticipation effects to unionism for prospective members and covered nonmembers of both genders. Workers go on to report, on average, a significant net increase in overall job satisfaction at the year unionization occurs. Nonetheless, adaptation to unionism is complete within the first few years of joining a unionized firm. One hypothesis for this is that workers adapt their reported satisfaction over time to support their union bargaining efforts, which would be consistent with the explanation given by Freeman and Medoff (1984) of union's role in fanning the flame of discontent to the management during contract negotiations.

JEL Classification: J28, J5

Keywords: union coverage, union membership, job satisfaction, anticipation, adaptation, free-rider, longitudinal

Corresponding author:

Nattavudh Powdthavee

Department of Economics \& Related Studies

University of York

Heslington

York YO10 5DD

Great Britain

E-mail: np517@york.ac.uk 


\section{Introduction}

Perhaps one of the most well-known results in trade union and collective-bargaining literature is that from studies which find that union members are generally less satisfied with their jobs compared to nonmembers (see, e.g., Freeman, 1978; Borjas, 1979; Clark, 1997; Heywood, Siebert, \& Wei, 2002; Guest \& Conway, 2004; Meng, 1990; Renaud, 2002; Garcia-Serrano, 2009; Miller, 2008). This finding is deeply counterintuitive: Given that unionism often leads to more bargaining power and improved working conditions, one would expect it to lead to greater job satisfaction rather than less.

Freeman $(1978,1980)$ and Freeman and Medoff (1984) argue that the negative relationship between unionism and job satisfaction is a reflection of the role of unions as a "voice" for workers. Unionized workers are, in other words, encouraged by their union to express their discontent and grievances to the management, thereby raising the level of apparent job dissatisfaction among union members during contract negotiations. This is reflected in the finding that union members often express lower job satisfaction than nonmembers but express relatively high satisfaction with their unions (Fiorito, Gallagher, \& Fukumi, 1988; Jarley, Kuruvilla, \& Casteel, 1990). Duncan (1976) and Borjas (1979) propose that unionized jobs are inherently unpleasant and that, hence, a union wage effect can be viewed as a compensating differential for lowered job satisfaction overall. Moreover, Borjas (1979) argues that the impact of unionism on job satisfaction will also depend on the strength of the trade union to maintain the "full wage" and non-pecuniary job rewards. An inverse relationship is therefore possible if there is a significant discrepancy between what is expected by union members and what they receive in actuality. More recently, Bryson, Capellari, and Lucifora (2004) hypothesized that the negative relationship between unionism and job satisfaction may reflect the role of workers' unobserved heterogeneity, i.e., those who 
are intrinsically unhappy with their jobs are more likely to join the union and involve themselves in union activities than those who are not, thus leading to lower job satisfaction among union members relative to nonmembers.

The above arguments imply one important empirical implication, namely, if we are able to control sufficiently for individual and workplace heterogeneity, as well as allowing for the selection effect into a unionized job, then it may be possible to estimate a net effect of union membership on job satisfaction that is both causal and nonnegative. However, owing to data limitations (restricted controls and unrepresentative or small samples), only a handful of studies have been able to satisfy a number of the above requirements. The notable examples are Bryson et al. (2004), Bender and Sloane (1998), Gordon and Denisi (1995), and Ranaud (2002). Using linked employer-employee data from the 1998 Workplace Employee Relations Survey (WERS) for the U.K., Bryson et al. (2004) found that unionized workers report, on average, significantly lower levels of job satisfaction compared to nonunionized workers. However, they found that the well-being gap between the two groups becomes statistically insignificant once individual heterogeneity, establishment heterogeneity, and selection effects are controlled for in the estimation. Based on this finding, they argue that unions are successful at securing an attractive wage package for their members only insofar as that it is large enough to offset their intrinsic dissatisfaction generated by higher expectations about their job. Using the Social Change and Economic Life Initiative (SCELI) data set, Bender and Sloane (1998) controlled for the selection into being a union member by using employee perceptions of employer attitudes as instruments. Treating union membership as exogenous, they were able to show that the correlation between union membership and job satisfaction, albeit negative, is not statistically significantly different from zero. Finally, Gordon and Denisi (1995) and Ranaud (2002) found statistically insignificant effects of union 
membership on either job satisfaction or the intent to quit once working conditions are controlled for.

The finding that trade unions do nothing to improve workers' job satisfaction is a bitter pill to swallow for many prospective union members. Yet it is the conclusion upon which many studies have come to agree. This paper, however, proposes that the discussion regarding the role of union membership on job satisfaction may be far from over.

In this paper, I argue that previous empirical studies have consistently failed to take the following information into account when making their analysis on the impact of unionism on job satisfaction: (a) levels of workers' job satisfaction in the periods before and after joining the union, and (b) the status of union coverage of the control group. As a result, previous studies, which have mainly been studies of cross-section data sets, have failed to consider that

(1) the estimated effects of unionism on job satisfaction at cross-sections may not only suffer from unobserved heterogeneity - in that unhappy workers are more likely to select themselves into a unionized job - but may also be biased owing to confounding time-varying endogenous effects. For example, there may be significant anticipation effects to individuals joining a trade union, e.g., the same worker may have been experiencing a decline in job satisfaction for some years before she decides to become a union member. It is therefore possible that there could be a positive impact on job satisfaction in the first year of joining the union, which would not have been picked up before in prior studies;

(2) there may be a significant free-rider problem among covered nonmembers (workers who are covered by collective-bargaining agreements but are not union members) that, if unaccounted for, can lead to an underestimated effect of union membership on job satisfaction; and 
(3) there may be significant mean-reversion or adaptation effects to the initial impact of union membership on job satisfaction, which could lead to an underestimation of the union effect.

Taking the above factors into account, it may therefore be possible to estimate a union coverage effect that is both positive and statistically significant. Since Richard Freeman's (1984) caveats against the use of short-run longitudinal data sets to estimate the impact of union membership (simply because the associated measurement error bias stemming from the fact that workers hardly change their union status in short-run panels is too great), we now have many rich, long-run micro-panel data sets, with a reasonably good number of observations of those who change their membership status over time, at our disposal. This paper uses eleven years (Waves 5-15) of the British Household Panel Surveys (BHPS) to study the leads and lags in job satisfaction to having a recognized union at the workplace for (i) all workers who went on to be employed at a unionized firm, with this sample split further into (ii) prospective union members, and (iii) prospective covered nonmembers.

Section II briefly discusses the psychological concepts of anticipation and adaptation, as well as the free-rider problem. Data and analytical strategy are outlined in Section III. Section IV reports the results. Section V concludes.

\section{Concepts}

\section{A. Anticipation effects}

When we think of anticipation, we think of the effect of an event of interest on well-being before it actually occurs (Clark, Diener, Georgellis, \& Lucas, 2008; Frijters, Johnston, \& Shields, 2008). In the context of unionism and job satisfaction, one hypothesis may be that 
non-union members go through a significant decline in their perceptions about work conditions over time, which leads them to join or form the trade union in the future. This can be captured empirically by looking at the coefficients on a series of lead variables (will form the union in the next 12 months, in the next 1-2 years, etc.) in job satisfaction equations. In the analysis of anticipation effects to unionism, an individual fixed effect must be introduced so that any negative effect of the lead variables will pick up anticipation rather than selection (where those who are inherently unhappy with their jobs are also those who are likely to join or form the union). Failure to take into account the anticipation effect may bias the union effect in the same direction as the usual selection bias.

\section{B. Free-rider problem}

Previous empirical studies on the impact of unionism on job satisfaction have often failed to distinguish between covered and uncovered nonmembers (usually all nonmembers are used as the reference group to union members). This would be acceptable if the decision to remain a nonmember at a unionized firm is exogenous, which may not always be the case (Chaison \& Dhavale, 1992; Booth, 1985; Booth \& Bryan, 2001). The results on the benefits of freerider status (employees who are covered by collective-bargaining agreements but not members) are mixed. In terms of the estimated wage differentials, Kahn (1980) and Belfield and Heywood (2001) showed that union threat effects by covered nonmembers have a positive impact on the nonunion wages which exceeds that of the average pay package received by nonmembers in the uncovered sector. Using WERS 1998 data sets, Booth and Bryan (2001) found evidence of zero wage premia between union members and covered nonmembers once union membership is instrumented. By contrast, Budd and $\mathrm{Na}$ (2000) found for the US, and Hildreth (1999) for the UK, that covered nonmembers do not receive 
the same wage premia as covered members. Nonetheless, in a more novel approach to identify the differences between the two groups, Clark (2001) found using the BHPS that a dissatisfied union member and a dissatisfied covered nonmember have a statistically the same probability to quit. In other words, his results supports the notion that union dissatisfaction is real rather than an artifact of institutional structures that make union members more likely to express dissatisfaction. However, he also found that a worker with low job satisfaction at a "union-recognized" workplace is less likely to quit than an identical worker at a workplace where a union is not recognized. In addition to this, Farley and Fiorito (1990) concluded that it is the union free-riders rather than non-covered workers who are significantly more likely to indicate a preference for pro-union voting intent, which is at odds with "right-to-work" advocates' view of free-riders as "principled conscientious objectors". Given these conflicting findings, further analysis that distinguishes between union members, covered nonmembers, and nonmembers in the uncovered sector is warranted ${ }^{1}$.

\section{Adaptation}

When we think of adaptation, we think of the processes that reduce the effects of repeated sensory and cognitive stimuli (see, e.g., Frederick \& Loewenstein, 1999). In other words, adaptation generally refers to the decline in satisfaction over time after the event has occurred. Empirical studies in this area have found significant evidence of adaptation to marriage and divorce (Lucas \& Clark, 2006; Zimmerman \& Easterlin, 2006), income (Di Tella, Haisken-DeNew, \& MacCulloch, 2005), disability (Oswald \& Powdthavee, 2008), and unemployment (Lucas, Clark, Georgellis, \& Diener, 2004). With regards to unionism, one could hypothesize that union members get 'used to' improvements in the pay package and

\footnotetext{
${ }^{1}$ It is worth noting here that there is no labor law that restricts workers' ability to free-ride in the UK.
} 
work conditions. After a period of satisfaction, the psychological effects of union membership adapt to a base level and cognitive changes in interests, values and goals set in. In this process, workers increase their expectation (or aspiration) level (Stutzer, 2004).

\section{Implementing a test}

\section{A. Empirical implications}

Are there anticipation effects to forming a union or a staff association to negotiate wages and work conditions with the management? Is there a free-rider problem in the covered sector? Do union workers adapt to their new work conditions? A test of these questions has to have a number of special features:

(i) individuals in the sample must be followed for a reasonably long period, so that information on them is available before and after joining a union-covered firm;

(ii) there needs to be a control group who does not join a union-covered firm;

(iii) A distinction between union members and nonmembers at a unionized firm can be made within the data set;

(iv) the sample should be representative of the working age population;

(v) a set of other job-related variables, particularly on occupation, has to be available in the data set, so that confounding influences can be differenced out.

No study of this type has apparently been published in either economic or industrial relation literature.

\section{B. Data}


The main data set comes from Waves 5-15 of the British Household Panel Survey (BHPS).

The BHPS is a nationally representative longitudinal data of British households, contains over 10,000 adult individuals (it interviews every adult member in the sampled households), and has been conducted between September and Christmas each year since 1991 (Taylor et al., 2002$)^{2}$.

In every wave since Wave 1, individuals were asked to rate how satisfied they are with four different aspects of their job: total pay, job security, satisfaction with work itself, and hours of work ${ }^{3}$. Each of these criteria was to be given a number from one to seven, with one representing "very dissatisfied" and 7 "very satisfied". Finally, individuals asked about their overall job satisfaction: "All things considered, how satisfied or dissatisfied are you with your present job overall using the same 1 - 7 scale?"

This paper also draws upon two questions regarding trade union status in the BHPS:

(1) Is there a trade union, or a similar body such as a staff association, recognised by your management for negotiating pay or conditions for the people doing your sort of job in your workplace?

\section{(2) Are you a member of this trade union/association?}

Three empirical categories of trade union status are discussed in this paper. The first category is having a recognized trade union or a staff association to bargain over pay and work conditions at the workplace or 'Union Coverage', which includes all workers working in unionized firms. The other two categories are broken-down by union membership status, which are 'Union Members' and 'Covered Nonmembers'.

\footnotetext{
${ }^{2}$ The BHPS wave 1 consists of some 5,500 households and 10,300 individuals drawn from 250 areas of Great Britain. Additional sample of 1,500 households in each Scotland and Wales were added to the main sample in 1999, and in 2001 a sample of 2,000 households was added in Northern Ireland, making the panel suitable for UK-wide research (see http://www.iser.essex.ac.uk/survey/bhps).

${ }^{3}$ Participants were also asked in selected BHPS waves (Waves 1-7) about their level of satisfaction with (i) promotion opportunities, (ii) relations with boss, and (iii) the use of initiative in their job, although these are not used in this paper's analysis.
} 
I consider all working age individuals (aged 16-65) in full-time employment (omitting the self-employed) who report a level of overall job satisfaction in any given wave. Among those who are in full-time employment, the response rates to the job satisfaction questions are very good $(=88 \%)$. I also restrict the sample to consist only of those who do not change their workplace throughout the panel (this is so to avoid the identification problem of the union effect on job satisfaction between job changers and newly unionized workers). In addition to this, because over $85 \%$ of workers in the public sector are covered by the trade union compared to $33 \%$ of workers in the private sector, there will be significantly less number of workers moving in and out of union jobs in the former than in the latter. For this reason, I focus in this paper on the dynamic effects of union on job satisfaction for workers in the private sector who do not change their jobs during their time in the panel ${ }^{4}$. This produces a nationally representative sample of 23,259 observations (5,446 individuals) for men and 17,926 observations (4,838 individuals) for women. Of those, 9,635 observations for men and 5,970 observations for women had a trade union, or a similar body such as a staff association, in their workplace. Approximately $61 \%$ of men and $50 \%$ of women in unionized firms are members of union or a staff association. The data are unbalanced, in that not every one is present in all eleven waves. Because the impacts of union on job satisfaction may be different for men and women (see, e.g., Clark, 1997), I conduct all statistical analysis separately by gender. The distribution of responses to the domain-specific job satisfaction questions as well as overall job satisfaction question is reported in Table 1. Because the vast majority of individuals can be tracked for far shorter periods of time than the available eleven BHPS waves, I concentrate only up to four years before and three years after union coverage. Finally, it is worth mentioning that, unlike some job satisfaction surveys which are conducted by the respondent's employer, the responses to the question on job satisfaction in the BHPS

\footnotetext{
${ }^{4}$ I thank Alan Carruth for this suggestion.
} 
are anonymous and conducted by an independent surveyor (again, see, Taylor et al, 2002). What this implies is that self-rated job satisfaction scores should not be influenced by whether or not the respondent's employer will find out who 'voiced' their dissatisfactions.

\section{Analytical Strategy}

The first equation will consider the lead and lag effects of union coverage on job satisfaction. Here, I follow the method outlined in Frijters et al. (2008) and estimate the following lead and lag equation:

$$
\begin{aligned}
& J S_{i t}=\beta_{-4} U_{-4, i t}+\beta_{-3} U_{-3, i t}+\beta_{-2} U_{-2, i t}+\beta_{-1} U_{-1, i t}+ \\
& \beta_{0} U_{0, i t}+\beta_{1} U_{1, i t-1}+\beta_{2} U_{2, i t}+\beta_{3} U_{3, i t}+X_{i t}^{\prime} \delta+u_{i}+\varepsilon_{i t},
\end{aligned}
$$

where $J S$ represents job satisfaction. Here, $U_{-4}$ represents a dummy variable that takes a value of 1 if the individual will be covered by a union in the following 3 to 4 years. The other leading $U$ dummies are defined similarly. If there is a lead effect to being covered by a union, then we would expect to see the lead coefficients to be zero or negative, and to be more negative the closer the periods of union coverage becomes. By contrast, the adaptation effects to being covered by a union are captured by three dummies: Union coverage 1-2 years, Union coverage 2-3 years, and Union coverage 3 years or more. Union coverage of less than one year duration, $U_{0}$, is identified by being covered today but not in the previous interview. Coverage of 1-2 years is identified by $U_{t}=1, U_{t-1}=1$ and $U_{t-2}=0$. Longer lags are defined analogously. If there is no important well-being effect from working at a unionized firm, so that being covered by a union does nothing to improve the employees' job satisfaction immediately, then we would expect $\beta_{0}$ to take some negative values. If there is no adaptation 
to this union effect, then we would expect the later values of $\beta$ to have the same negative values as $\beta_{0}$. Conversely, if there is a complete adaptation to being covered by collectivebargaining agreements, then later values of $\beta$ will be insignificant: being covered by a union long enough is the same as not being covered at all. With respect to other parameters, $X$ represents a vector of standard controls, which includes dummies for different age groups, marital status, number of hours normally worked per week, temporary job status, opportunity for promotion, real annual personal income, work size, education level, health, as well as social class, occupational, regional and wave dummies (see, e.g., Clark, 1997); $\varepsilon_{i t}$ is the error term. The individual fixed effects, $u_{i}$, is included in the equation so that we are effectively following the same individual through different periods prior to being employed at a unionized firm. The descriptive statistics for some of the variables used in this paper's analysis are reported in Table A1.

To test for the welfare impacts of union coverage on workers with free-rider status, i.e. covered nonmembers, Equations (1) can be rewritten to distinguish between covered members and covered nonmembers:

$$
J S_{i t}=\beta \sum_{k=-4}^{3} U_{k, i t}+\theta \sum_{m=-4}^{3} U M_{m, i t}+\lambda \sum_{n=-4}^{3}\left(U_{n, i t} \times U M_{n, i t}\right)+X_{i t}^{\prime} \delta+u_{i}+\varepsilon_{i t} .
$$

where $U M$ and $U N$ are respectively dummies representing covered members and covered nonmembers. By interacting between lead and lag dummies of both union coverage and union membership, I am able to control for the timing of becoming a member of either a staff association or a union as some workers may decide to become a member in their second or third year rather than in their first year of their firm becoming union-covered. To interpret the coefficients, $\beta_{3}$, for example, represents the well-being impact of having worked in a union- 
covered firm for at least three years, whilst the $\operatorname{sum} \beta_{3}+\theta_{3}+\lambda_{3}$ represents the well-being impact of being a union member in a union-covered firm for at least three years. In the case where all $U M$ variables equal to zero, $\beta_{3}$ on its own can be interpreted as the well-being impact of remaining a nonmember in a covered firm for at least three years. The number of observations of the various lags and leads are presented in Table A2 in the appendix.

This set-up allows us to carry out simple tests of whether the dynamics of job satisfaction differ significantly between covered members, covered nonmembers, and uncovered nonmembers. One hypothesis is that the anticipation effect, if any, will be more prominent amongst those who went on to become a covered member in the lead equation, compared to covered nonmembers. Moreover, if there is evidence of union free-riding (in that there are no significant differences in terms of job satisfaction between union members and covered nonmembers) then we would expect all of the values of $\beta$ to take some positive numbers, whilst all of the sums of $\theta+\lambda$ are expected to be statistically insignificantly different from zero.

\section{Longitudinal results}

\section{A. Union coverage}

Are workers in a union-covered firm more dissatisfied with their jobs compared to nonmembers? A first look at the raw data evidence suggests that they are. Figures 1A and 1B respectively show the reported levels of overall job satisfaction for men and women working in the covered and uncovered sector, as well as the $t$-statistic from the test of identical means between the two. We can see from both figures that, in every wave of the BHPS, workers in the uncovered sector report higher scores of overall job satisfaction compared to workers employed in the covered sector. Moreover, for eight of the eleven waves for men and nine of 
the eleven years for women, the differential is easily significant at the $5 \%$ level. This is consistent with previous studies that found a negative association between unionism and job satisfaction (Freeman, 1978; Borjas, 1979; Clark, 1997).

Are union workers always more dissatisfied with their jobs compared to nonunion workers? To answer this question, Table 2 presents within-person evidence of the dynamics of overall job satisfaction, which is measured cardinally, four years before and three years after employment at a unionized firm or a firm with a recognized staff association.

As anticipated, there is indeed a significant lead effect in overall job satisfaction one year prior to being covered by either a union or a staff association; the lead coefficient at $T-1$ is negative and statistically significant at the $1 \%$ mark for both men and women (although the drop took place earlier for men, at $T-2$ ). Given that individual fixed effects are controlled for in the regressions, the observed drop in the level of job satisfaction one year prior to being covered is independent from the negative selection effect - i.e., people who are inherently unhappy with their jobs are more likely to become union members in the future than those who are not unhappy (see, e.g., Bender \& Sloane, 1998; Bryson et al., 2004). In other words, what this result implies is that, for this particular sample of male and female workers, instead of quitting their jobs following a significant drop in their job satisfaction, they would go on to form either a union or a staff association to negotiate for better pay and working conditions in the following year. It may also be the case that organizers of a prospective union or staff association encourage workers to voice their dissatisfaction at period $T-1$, which would in turn act as a justification for the formation of either a union or staff association at $T$. This explanation is consistent with that proposed by Freeman and Medoff (1984), although the difference in the present case is that, instead of an existing union fanning the flames of discontent for bargaining purposes, organizers of a prospective union or staff association may 
encourage workers to express their discontentment and grievances early, before either organization is formed.

What is the contemporaneous effect of union coverage on overall job satisfaction? Conditioning for individual fixed effects and personal and workplace characteristics, we can see that the net effects from not being covered by either a union or a staff association to being covered, i.e., between $T-1$ and $T$, for genders are positive, sizeable, and statistically significant at the $1 \%$ level. The estimated net union coverage effects (the coefficient for union coverage during year $0-1$ minus the coefficient for union coverage within the next year) for men and women are $0.124[S . E .=0.041]$ and $0.201[S . E .=0.051]$, respectively. The results contrast with the popular finding of a negative relationship between union and job satisfaction. They are also inconsistent with the existing theory that workers are encouraged upon becoming union members by their union to voice their dissatisfactions about their job and working environment to the management (Freeman \& Medoff, 1984). Instead, the results seem to support one of the more intuitive ideas about the role of trade unions, namely, that trade unions are there to improve the well-being of those associated with them. Nevertheless, it is worth noting that, despite the positive net union coverage effect being observed at $T$ for both male and female workers, job satisfaction remains, on average, either the same as, in the case of men, or significantly below, in the case of women, that of workers who reported to be in the uncovered sector throughout the sampling period.

This improvement in well-being, however, does not seem to last very long; within the first two years of being covered by collective-bargaining agreements, there is a complete mean-reversion or adaptation effect. Put simply, it takes only two years of being covered by either a union or a staff association for workers to become just as dissatisfied about their jobs as they used to be one year before the unionization occurred. One psychological explanation for this is that workers increase their expectation (or aspiration) level very soon after 
unionization has occurred. Another plausible explanation, which is more strategic than psychological, is that this further drop in workers' job satisfaction is not "real" and that the heightening of the level of discontent is there only to support their union's bargaining efforts (Fiorito et al., 1988). ${ }^{5}$ Workers, in other words, adapt their reported satisfaction over time to support their union in its bargaining endeavors. ${ }^{6}$

Table 3 examines the dynamic effects of union coverage on satisfaction with total pay, satisfaction with job security, satisfaction with work itself, and satisfaction with hours worked. Looking across the columns of the table, we can see that the net union coverage effect is both positive and statistically significant at conventional levels in two out of four domain-specific job satisfaction equations for men, and in three out of four for women. The largest of these effects is observed in the satisfaction-with-pay regressions: A move from union or staff association coverage within the next year to being covered by collectivebargaining agreements is associated with a 0.16 -point increase in satisfaction with pay for men and a 0.22-point increase for women. Given that income is controlled for in the satisfaction equations, we can naturally interpret these net union coverage effects upon workers' satisfaction with pay as non-pecuniary. There is evidence, in other words, that workers become significantly happier in the first year of unionization about their expected payments in the future. It is also worth noting that these positive net union coverage effects are often preceded by one or two years of significant drops in workers' satisfaction levels, either with their pay, job security, or even with work itself, beyond what is normally experienced by those who remained in nonunionized firms throughout the panel. Workers then go on to report a significant drop in the level of satisfaction with both job security and work itself in the second year of being covered by a union or a staff association. However,

\footnotetext{
${ }^{5}$ It is also possible to follow workers before and after the de-unionization of their firm. Though not shown here, there is a significant improvement in workers' job satisfaction following de-unionization. Workers, in other words, become statistically significantly happier with their jobs after the de-unionization has occurred.

${ }^{6}$ It is possible that there could be further adaptation to unionism beyond $\mathrm{T}+3$. However, since there are only a few hundred observations of these individuals in the sampled data, we can only speculate about the trend.
} 
perhaps rather unexpectedly, there appears to be zero adaptation to the positive net union coverage effect on the satisfaction-with-pay equation for both male and female workers. What this implies is that the effect of being covered by collective-bargaining agreements upon satisfaction with pay never ceases to be positive even after four or more years spent at a unionized firm, i.e., all else being equal, the individual would have remained significantly dissatisfied with his or her pay if unionization did not take place at $T$.

\section{B. Union members versus union "free-riders"}

Table 4 goes on to estimate Equation (2) in order to examine whether the results obtained in Table 2 vary significantly by union membership status. The two questions of interest are whether 1) the negative anticipation effect upon overall job satisfaction found in the previous section is primarily driven by prospective union members rather than prospective union freeriders (or covered nonmembers) and 2) there are any clear psychological benefits to union free-riding, i.e., the post-union impact on job satisfaction is statistically the same between union members and nonmembers in unionized firms. For simplicity, only the coefficients for those who have either been a union member or remained a nonmember since the first year of working for a union-covered firm are reported.

Table 4 presents a set of results that might have been difficult to predict. First, while there is a noticeable drop in the level of overall job satisfaction among male members one year before unionization occurs at $T$, the lead effect to being covered by collective-bargaining agreements is not statistically different from zero for male free-riders. A similar pattern between members and free-riders is obtained, on the other hand, for the female sample. Second, there appears to be some statistical evidence of a positive net union coverage effect among free-riders in the first year of unionization, which is more robust for women than for 
men. Third, there is strong adaptation to the positive union coverage effect following unionization for both members and free-riders of both genders. Finally, while there is evidence of free-riding generating positive satisfaction, it does not seem to generate any significant differences in overall job satisfaction over union members in general.

\section{Union satisfaction with pay premium}

The non-pecuniary impacts of union coverage on satisfaction with pay - or, in other words, how secure workers think they will be about their financial status in the future from working in a unionized firm - are quantitatively important as well as statistically significant. To get some ideas about the size of the coverage impacts on satisfaction with pay, the "Union Satisfaction with Pay Premium" (or USPP for short) can be calculated using the coefficient on pay and the estimated net union coverage effect obtained from the satisfaction with pay regression equations. Given that our pay variable is in a log form, the USPP equation can be written as follows:

$U S P P=Y \times\left(\exp \frac{\beta_{\text {union for } 0-1 \text { year }}-\beta_{\text {union within the next year }}}{\lambda_{\lg p a y}}-1\right)$,

where USPP refers to the additional income required to compensate an average nonmember before unionization occurs at $T-1$ to be just as satisfied with their total pay as an average worker who are covered by collective-bargaining agreements at $T, Y$ is the current real personal income, $\beta_{\text {union for } 0-1 \text { year }}$ represents the coefficient of being covered by a union or a staff association for $0-1$ year, $\beta_{\text {union within the next year }}$ is the reference coefficient for the lead effect 
to becoming union-covered within the next year, and $\lambda_{\lg p a y}$ is the estimated coefficient on $\log$ of real personal income.

To illustrate how USPP can be calculated for the first year of being covered by collective-bargaining agreements, the estimated net union coverage effects ( $\beta_{\text {union for } 0-1 \text { year }}-\beta_{\text {union within the next year }}$ ) are given by $0.159($ S.E. $=0.047)$ for men and 0.221 (S.E. $=$ 0.059) for women. Although not reported in the tables, the estimated coefficients on log of real personal income are $0.107($ S.E. $=0.024)$ for men and $0.064($ S.E. $=0.025)$ for women, respectively. Based on current average real earnings of $£ 18 \mathrm{k}$ (or $\$ 29^{7}$ ) per annum for male nonmembers and $£ 11 \mathrm{k}$ (or $\$ 18 \mathrm{k}$ ) per annum for female nonmembers, the USPP are approximately $£ 61 \mathrm{k}(\$ 98 \mathrm{k})$ and $£ 82 \mathrm{k}(\$ 131 \mathrm{k})$ for men and for women. In other words, an average male worker in the uncovered sector at $T-1$ would require an additional pay worth three times their current earning to feel indifferent about their wages as an average male worker in the covered sector at $T$. An average female worker in the uncovered sector at $T-1$, on the other hand, would require an additional pay worth up to seven times their current earning to be just as satisfied about their pay as an average female worker in the covered sector at $T$. Nonetheless, given that income is potentially endogenous in the satisfaction with pay equation, the interpretation of these results are only illustrative and should therefore be treated with care ${ }^{8}$.

\section{Conclusions}

\footnotetext{
${ }^{7}$ Exchange rate: $£ 1=\$ 1.44$ in March, 2009.

${ }^{8}$ Other USPP values and coefficients of other variables in the satisfaction with pay equation can be supplied on request.
} 
This paper utilizes data from the British Household Panel Survey (Waves 5-15) to study the relationship between job satisfaction and past, contemporaneous, and future union status. The main conclusions of this paper's findings can be set out as follows:

A) Anticipation (from $\boldsymbol{T}-\mathbf{4}$ to $\boldsymbol{T}-\mathbf{1}$ ). There is evidence to suggest that, on average, workers select themselves into a unionized firm at $T$ based on how unhappy they have become with their jobs in the periods before $T$. This finding is consistent with the view that a worker's decision on whether or not to join a unionized firm is endogenously determined (see, e.g., Hildreth, 1999; Budd \& Na, 2000).

B) Net union coverage effect (at $\boldsymbol{T}$ ). In contrast to the popular findings of zero or even negative effects of union coverage on job satisfaction, this paper finds a positive and significant improvement in workers' job satisfaction in the first year of unionization, an improvement that is statistically robust in both male and female samples. Freeriding also generates positive satisfaction, which seems consistent with studies that find beneficial effects from free-riding on wages (Booth, 1985; Chaison \& Dhavale, 1992; Booth \& Bryan, 2004). The impact of union coverage on satisfaction with pay is large, as indicated by the calculated USPP, and is larger for women than for men.

C) Adaptation (from $\boldsymbol{T}+\mathbf{1}$ to $\boldsymbol{T}+\mathbf{3}$ ). Evidence on adaptation to working in the covered sector is mixed. In terms of overall job satisfaction, there is evidence of a complete adaptation to the initial increase in job satisfaction within one year of working at a unionized firm for both men and women. There is, however, little adaptation to the initial increase in satisfaction with pay following unionization. An alternative explanation to the evidence of a continuing decline in satisfaction in the years that follow unionization is that workers may be adapting their reported satisfaction over 
time to support their union's bargaining efforts, an explanation that would be consistent with that given by Freeman and Medoff (1984).

These results are important for several reasons. First, the evidence of significant anticipation effects to unionism implies that, in addition to the usual unobserved heterogeneity, there are also unobservable time-varying differences between prospective union workers (both members and nonmembers) and other "permanent" nonmembers in the uncovered sector that correlate with the job satisfaction of individuals in these two groups. Both types of endogeneity will therefore have to be taken into account if one wishes to estimate the causal effects of unionism on job satisfaction. Second, because of the potential free-rider problem, it is important to make clear distinctions between union members, covered nonmembers, and other nonmembers when constructing a union membership variable. Third, because of adaptation to unionism, it seems pertinent for future studies to control also for the number of years that individuals have been members of the trade union.

The fourth consequence of these results is purely descriptive or positive. The evidence of a positive and statistically significant coverage effect on all workers at $T$ suggests that there may in fact be no paradox at all to unionism. In other words, the workers' decision to form a union or a staff association to negotiate their pay and working environment on their behalf is rational in the sense that they do indeed gain more satisfaction from their jobs in the first year of unionization. However, as the evidence of this paper clearly suggests, we would also need to take into consideration the adaptation effects to unionism if we want to build a more realistic and accurate economics model of trade unions.

The results of this study also give rise to many important, normative questions. For example, how should unions prevent the subsequent decline in their members' overall job satisfaction over time? Is the decline in satisfaction actually real? Should any actions be taken 
on union free-riders if they clearly benefit - not just financially but also psychologically from working in a union-covered firm?

I began by noting the famous paradox of dissatisfied union members. The above results seem to point toward a reverse conclusion - that there is indeed a statistically significant psychological benefit to becoming a union member, at least in the first year of union membership. Whether this boost in job satisfaction following unionization is real or not, however, remains to be seen. 


\section{Reference}

Belfield, Clive R., and John S. Heywood. 2001. Unionization and the pattern of nonunion wages: evidence for the UK. Oxford Bulletin of Economics and Statistics, 63(5), $577-598$

Bender, Keith A., and Peter J. Sloane. 1998. Job satisfaction, trade unions, and exitvoice revisited. Industrial and Labor Relations Review, 51, 222-240.

Booth, Alison L. 1985. The free-rider problem and a social custom model of trade union membership. Quarterly Journal of Economics, 100(1), 253-261.

Booth, Alison L., and Mark L. Bryan. 2004. The union membership wage premium puzzle: Is there a free-rider problem? Industrial and Labor Relations Review, 57(3), 402-421.

Borjas, George J. 1979. Job satisfaction, wages, and unions. Journal of Human Resource, 14(1), 21-40.

Bryson, Alex, Lorenzo Cappellari, and Claudio Lucifora. 2004. Does union membership really reduce job satisfaction? British Journal of Industrial Relations, 42(3), 439-459.

Budd, John W., and In-Gang Na. 2000. The union membership wage premium for employees covered by collective-bargaining agreements. Journal of Labor Economics, 18(4), $783-807$

Chaison, Gary N., and Dhavale, Dileep G. 1992. The choice between union membership and free-rider status. Journal of Labor Research, 13(4), 355-369.

Clark, Andrew E. 1997. Job satisfaction and gender: Why are women so happy at work? Labour Economics, 4, 341-372.

Clark, Andrew E. 2001. What really matters in a job? Hedonic measurement using quit data. Labour Economics, 8, 223-242. 
Clark, Andrew E., Ed Diener, Yannis Georgellis and Richard E. Lucas. 2008. Lags and leads in life satisfaction: a test of the baseline hypothesis. Economic Journal, 118(529), F222-F243.

Di Tella, Rafael, John P. Haisken-DeNew, and Robert MacCulloch. 2005. Happiness adaptation to income and to status in an individual panel. Unpublished manuscript, Harvard Business School.

Duncan, Greg J. 1976. Earnings functions and non-pecuniary benefits. Journal of Human Resources, 11, 462-483.

Freeman, Richard B. 1978. Job satisfaction as an economic variable. American Economic Review, 68, 135-141.

Freeman, Richard B. 1980. The exit-voice tradeoff in the labor market: Unionism, job tenure, quits, and separations. Quarterly Journal of Economics, 94(4), 643-673.

Freeman, Richard B. 1984. Longitudinal analyses of the effects of trade unions. Journal of Labor Economics, 2(1), 1-26.

Freeman, Richard B., and James L. Medoff. 1984. What do unions do? New York: Basic Books.

Frederick, Shane, and George Loewenstein. 1999. Hedonic adaptation. In E. Diener, N. Schwarz and D. Kahneman (Eds.) Hedonic Psychology: Scientific Approaches to Enjoyment, Suffering, and Well-being. Russell Sage Foundation. New York. 302-329.

Frijters, Paul, David W. Johnston, and Michael A. Shields. 2008. Happiness dynamics with quarterly life event data. IZA Discussion Paper No. 3604.

Garcia-Serrano, Carlos. 2009. Job satisfaction, union membership and collectivebargaining. European Journal of Industrial Relations, 15, 91-111. 
Gordon, Michael E., and Angelo S. Denisi. 1995. A re-examination of the relationship between union membership and job satisfaction. Industrial and Labor Relations Review, 48: $222-36$.

Guest, David E., and Conway, Neil. 2004. Exploring the paradox of unionized worker dissatisfaction. Industrial Relations Journal, 35(2), 102-121.

Heywood, John S., Stanley Siebert, and Xiangdong Wei. 2002. Worker sorting and job satisfaction: The case of union and government jobs. Industrial and Labor Relations Review, 55, 595-609.

Hildreth, Andrew K.G. 1999. What has happened to the union wage differential in Britain in the 1990s? Oxford Bulletin of Economics and Statistics, 61(1), 5-31.

Kahn, Lawrence M. 1980. Union spillover effects on organized labor market. Journal of Human Resources, 15(1), 87-98.

Evans, Martin G., and Daniel A. Ondrack. 1990. The role of job outcomes and values in understanding the union's impact on job satisfaction: A replication. Human Relations, 43, 401-418.

Fiorito, Jack, Daniel G. Gallagher, and Cynthia V. Fukumi. 1988. Satisfaction with union representation. Industrial and Labor Relations Review, 41, 294-307.

Jarley, Paul, and Jack Fiorito. 1990. Associate membership: unionism or consumerism? Industrial and Labor Relations Review, 43(2), 209-224.

Jarley, Paul, Sarosh Kuruvilla, and Douglas Casteel. 1990. Member - Union relations and union satisfaction. Industrial Relations, 29, 128-134.

Lucas, Richard E., Andrew E. Clark, Yannis Georgellis, and Ed Diener. 2004. Unemployment alters the set-point for life satisfaction. Psychological Science, 15, 8-13.

Lucas, Richard E., and Andrew E. Clark. 2006. Do people really adapt to marriage? Journal of Happiness Studies, 7, 405-426. 
Luttmer, Erzo F.P. 2005. Neighbors as negatives: Relative earnings and well-being. Quarterly Journal of Economics, 120, 963-1002.

Meng, Ronald. 1990. The relationship between union and job satisfaction. Applied Economics, 22(12), 1635-1648.

Miller, Paul W. 2008. Trade unions and job satisfaction. Australian Economic Paper, 29(55), 226-248.

Oswald, Andrew J., and Nattavudh Powdthavee. 2008. Does happiness adapt? A longitudinal study of disability with implications for economists and judges. Journal of Public Economics, 92, 1061-1077.

Renaud, Stephane. 2002. Rethinking the union membership/job satisfaction relationship: some empirical evidence in Canada. International Journal of Manpower, 23(2), 137-150.

Stutzer, Alois. 2004. The role of income aspirations in individual happiness. Journal of Economic Behavior and Organization, 54(1), 89-109.

Taylor, Marcia F., John Brice, Nick Buck, and Elaine Prentice-Lane. 2002. British Household Panel Survey User Manual. Colchester: University of Essex.

Zimmerman, Anke, and Richard A. Easterlin. 2006. Happily ever after? Cohabitation, marriage, divorce, and happiness in Germany. Population and Development Review, 32, 511 528. 
Figure 1: Union coverage and job satisfaction in the UK

Fig 1a: Men
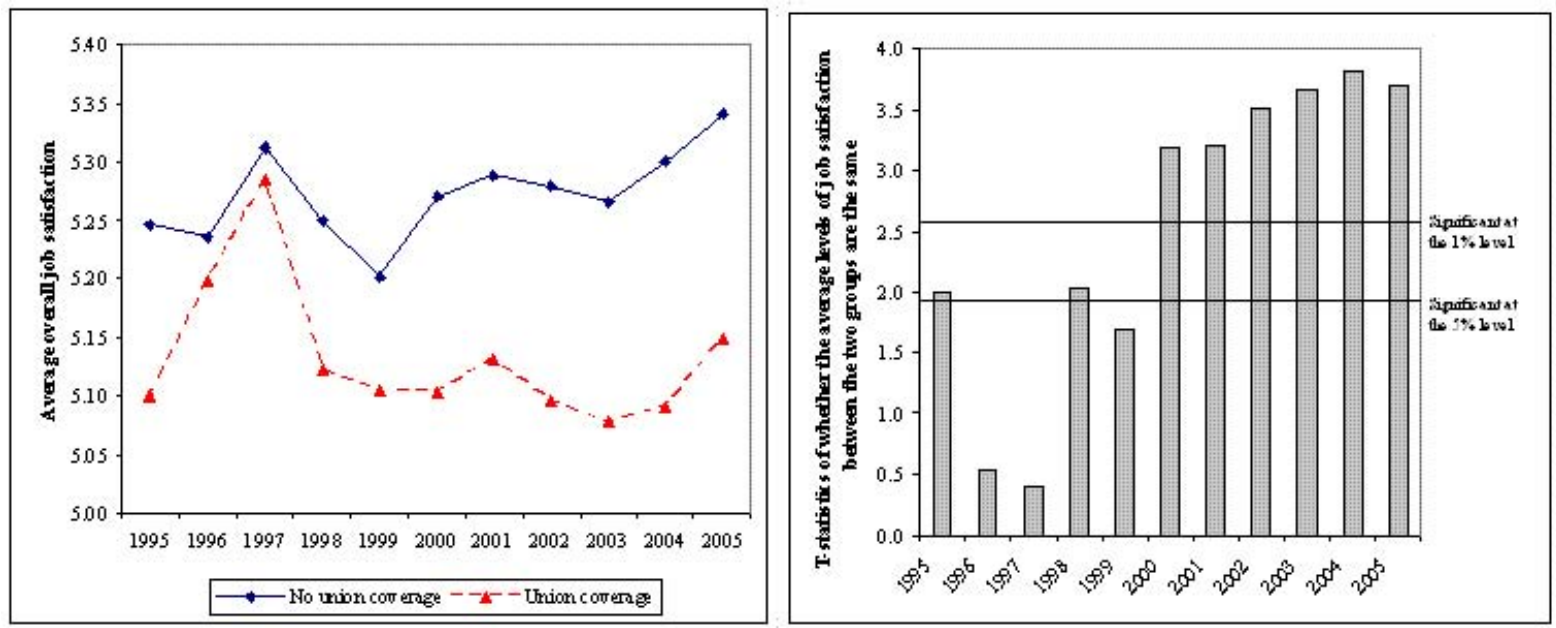

Fig 1b: Women
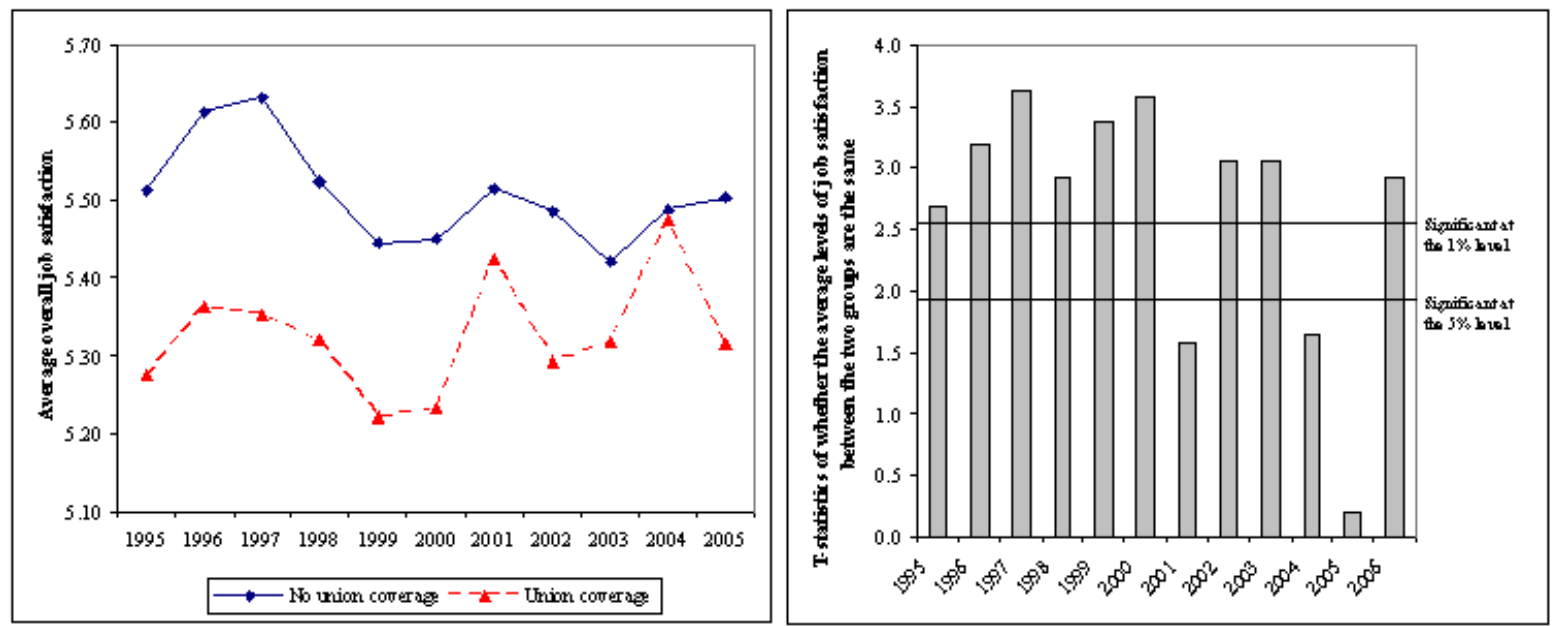
Table 1: Job Satisfaction, Pooled BHPS, Waves 5-15 (Percentages \%)

\begin{tabular}{|c|c|c|c|c|c|}
\hline Men & Total pay & $\begin{array}{c}\text { Job } \\
\text { security }\end{array}$ & $\begin{array}{l}\text { Work } \\
\text { itself }\end{array}$ & $\begin{array}{c}\text { Hours } \\
\text { worked }\end{array}$ & Overall \\
\hline Not satisfied at all & 3.58 & 2.98 & 1.69 & 2.47 & 1.57 \\
\hline 2 & 5.24 & 3.33 & 2.80 & 3.71 & 3.17 \\
\hline 3 & 14.07 & 7.72 & 6.53 & 11.44 & 7.53 \\
\hline $\begin{array}{l}\text { Not } \\
\text { satisfied/dissatisfied }\end{array}$ & 9.27 & 10.01 & 9.09 & 12.68 & 9.69 \\
\hline 5 & 26.36 & 19.96 & 21.85 & 23.43 & 24.65 \\
\hline 6 & 34.12 & 36.97 & 42.67 & 35.51 & 43.61 \\
\hline Completely satisfied & 7.36 & 19.04 & 15.36 & 10.75 & 9.78 \\
\hline Women & Total pay & $\begin{array}{c}\text { Job } \\
\text { security }\end{array}$ & $\begin{array}{l}\text { Work } \\
\text { itself }\end{array}$ & $\begin{array}{c}\text { Hours } \\
\text { worked }\end{array}$ & Overall \\
\hline Not satisfied at all & 4.00 & 2.50 & 1.76 & 1.51 & 1.67 \\
\hline 2 & 4.92 & 2.39 & 2.73 & 2.51 & 2.62 \\
\hline 3 & 13.41 & 5.72 & 6.13 & 9.27 & 5.92 \\
\hline $\begin{array}{l}\text { Not } \\
\text { satisfied/dissatisfied }\end{array}$ & 7.04 & 7.26 & 6.82 & 7.74 & 6.41 \\
\hline 5 & 24.08 & 17.35 & 20.42 & 21.03 & 20.75 \\
\hline 6 & 35.86 & 38.98 & 42.83 & 38.35 & 46.80 \\
\hline Completely satisfied & 10.68 & 25.81 & 19.30 & 19.57 & 15.83 \\
\hline
\end{tabular}

Note: The figures represent proportion, so that the top left-hand number, for example, means that $3.58 \%$ of the men sample reported not being satisfied at all with their total pay. 
Table 2: Fixed effects job satisfaction regressions:

\section{Leads to and lags of union coverage}

\begin{tabular}{|c|c|c|}
\hline $\begin{array}{l}\text { Dependent variable: Overall job } \\
\text { satisfaction }\end{array}$ & Men & Women \\
\hline Union coverage 4 years hence & $\begin{array}{c}0.069 \\
{[0.080]}\end{array}$ & $\begin{array}{l}-0.037 \\
{[0.091]}\end{array}$ \\
\hline Union coverage 3 years hence & $\begin{array}{c}0.121 \\
{[0.066]+}\end{array}$ & $\begin{array}{l}-0.085 \\
{[0.080]}\end{array}$ \\
\hline Union coverage 2 years hence & $\begin{array}{l}-0.074 \\
{[0.055]}\end{array}$ & $\begin{array}{l}-0.045 \\
{[0.066]}\end{array}$ \\
\hline Union coverage within the next year & $\begin{array}{c}-0.128 \\
{[0.045]^{* *}}\end{array}$ & $\begin{array}{c}-0.347 \\
{[0.054]^{* *}}\end{array}$ \\
\hline Union coverage $0-1$ year & $\begin{array}{l}-0.003 \\
{[0.038]}\end{array}$ & $\begin{array}{c}-0.146 \\
{[0.048]^{* *}}\end{array}$ \\
\hline Union coverage $1-2$ years & $\begin{array}{c}-0.090 \\
{[0.045]^{*}}\end{array}$ & $\begin{array}{c}-0.210 \\
{[0.057]^{* *}}\end{array}$ \\
\hline Union coverage $2-3$ years & $\begin{array}{c}-0.080 \\
{[0.051]}\end{array}$ & $\begin{array}{c}-0.215 \\
{[0.066]^{* *}}\end{array}$ \\
\hline Union coverage 3 years or more & {$[0.045]^{* *}$} & {$[0.058]^{*} *$} \\
\hline $\begin{array}{l}\text { [Coeff.] Union coverage } 0-1 \text { year }- \text { [Coeff. }] \\
\text { Union coverage within the next year }=\end{array}$ & $\begin{array}{c}0.124 \\
{[0.041]^{* *}}\end{array}$ & $\begin{array}{c}0.201 \\
{[0.051]^{* *}}\end{array}$ \\
\hline Age: $26-35$ & $\begin{array}{l}-0.002 \\
{[0.044]}\end{array}$ & $\begin{array}{c}0.031 \\
{[0.053]}\end{array}$ \\
\hline Age: $36-45$ & $\begin{array}{l}-0.013 \\
{[0.065]}\end{array}$ & $\begin{array}{l}-0.002 \\
{[0.078]}\end{array}$ \\
\hline Age: $46-55$ & $\begin{array}{l}-0.049 \\
{[0.087]}\end{array}$ & $\begin{array}{l}-0.035 \\
{[0.104]}\end{array}$ \\
\hline Age: $56-65$ & $\begin{array}{c}0.008 \\
{[0.110]}\end{array}$ & $\begin{array}{l}-0.082 \\
{[0.132]}\end{array}$ \\
\hline Living with a partner & $\begin{array}{l}-0.017 \\
{[0.044]}\end{array}$ & $\begin{array}{l}-0.017 \\
{[0.052]}\end{array}$ \\
\hline Widowed & $\begin{array}{c}0.151 \\
{[0.230]}\end{array}$ & $\begin{array}{l}-0.175 \\
{[0.168]}\end{array}$ \\
\hline Separated & $\begin{array}{c}0.154 \\
{[0.079]+}\end{array}$ & $\begin{array}{c}-0.141 \\
{[0.082]+}\end{array}$ \\
\hline Divorced & $\begin{array}{c}0.103 \\
{[0.089]}\end{array}$ & $\begin{array}{c}0.034 \\
{[0.086]}\end{array}$ \\
\hline Never married & $\begin{array}{c}0.003 \\
{[0.059]}\end{array}$ & $\begin{array}{c}-0.114 \\
{[0.068]+}\end{array}$ \\
\hline $\begin{array}{l}\text { Ln(number of hours normally worked per } \\
\text { week) }\end{array}$ & $\begin{array}{c}-0.330 \\
{[0.058]^{* *}} \\
-0.073\end{array}$ & $\begin{array}{c}-0.175 \\
{[0.039]^{* *}} \\
-0.149\end{array}$ \\
\hline
\end{tabular}




\begin{tabular}{lcc} 
& {$[0.052]$} & {$[0.062]^{*}$} \\
Promotion opportunity & 0.369 & 0.368 \\
Ln(real annual personal income) & {$[0.021]^{* *}$} & {$[0.026]^{* *}$} \\
& -0.045 & -0.047 \\
Work size: $1-24$ & {$[0.021]^{*}$} & {$[0.022]^{*}$} \\
Work size: $25-199$ & 0.062 & 0.009 \\
& {$[0.048]$} & {$[0.064]$} \\
Education: completed first degree & -0.014 & -0.071 \\
& {$[0.043]$} & {$[0.058]$} \\
Education: completed higher degree & 0.043 & -0.161 \\
& {$[0.147]$} & {$[0.191]$} \\
Health: poor & 0.319 & 0.381 \\
& {$[0.246]$} & {$[0.479]$} \\
Health: fair & 0.206 & 0.000 \\
& {$[0.127]$} & {$[0.116]$} \\
Health: good & 0.260 & 0.136 \\
& {$[0.125]^{*}$} & {$[0.113]$} \\
Health: excellent & 0.395 & 0.235 \\
& {$[0.125]^{* *}$} & {$[0.113]^{*}$} \\
Constant & 0.485 & 0.329 \\
& {$[0.127]^{* *}$} & {$[0.116]^{* *}$} \\
Social class dummies (21) & 6.358 & 6.290 \\
Occupation dummies $(372)$ & {$[0.329]^{* *}$} & {$[0.351]^{* *}$} \\
Regional dummies $(20)$ & Yes & Yes \\
Wave dummies $(10)$ & Yes & Yes \\
Observations & Yes & Yes \\
Individuals & Yes & Yes \\
R-squared (within) & 23259 & 17926 \\
& 5446 & 4838 \\
& 0.0576 & 0.0605 \\
\hline
\end{tabular}

Note: + sig. at $10 \%,{ }^{*}$ sig. at $5 \%, * *$ sig. at $1 \%$. Standard errors are in parentheses. Reference groups: no union at the workplace, married, permanent job, no promotion opportunity, work size: 200 and more workers, education: lower than first degree, health: very poor. 
Figure 2: The dynamic effect of union coverage on job satisfaction

Fig 2a: Men

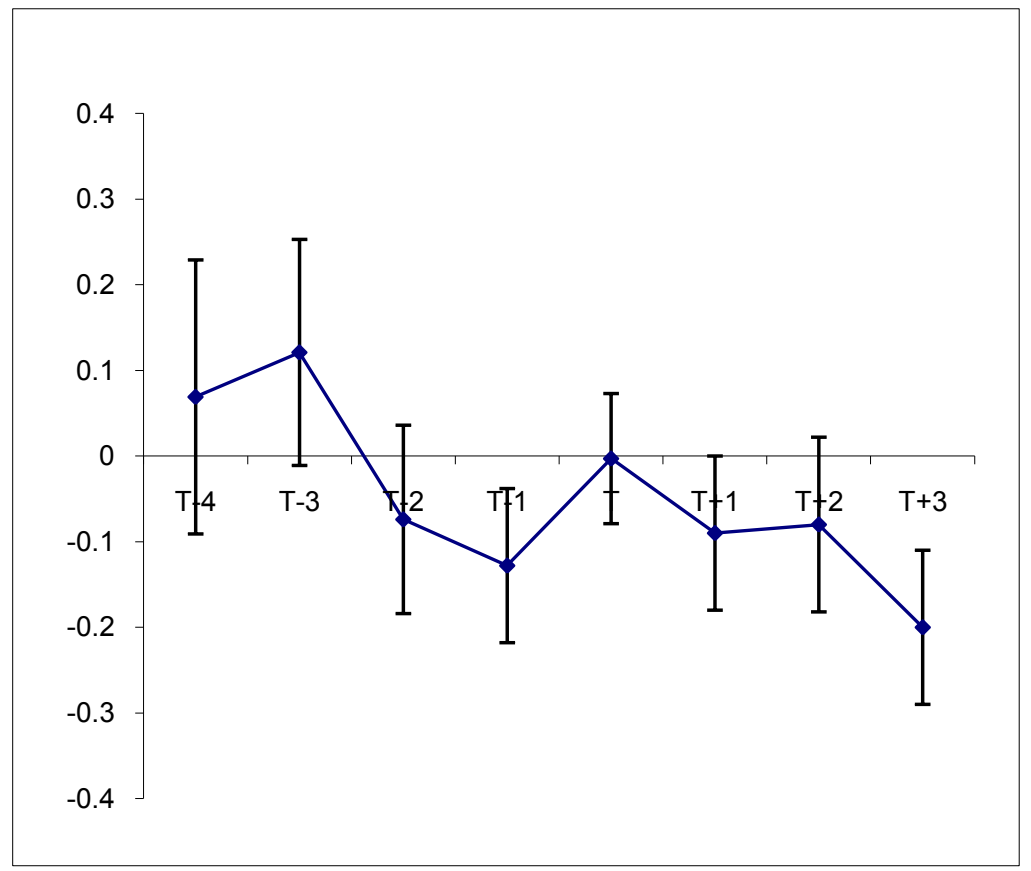

Fig 2b: Women

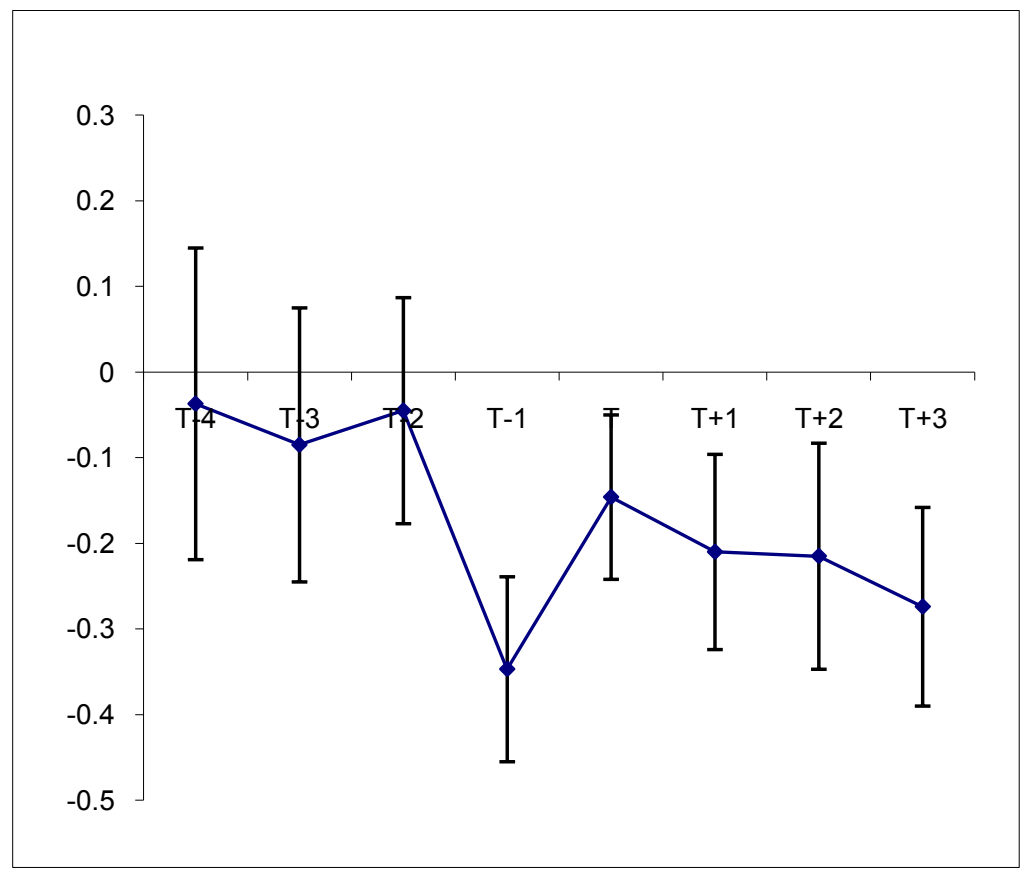

Note: Year $\mathrm{T}$ is the year of union coverage. 4 -standard-error bands (95\% C.I.) are reported: two S.E. above and two below. 
Table 3: Fixed effects regressions for each different aspect of job satisfaction

3a: Men

\begin{tabular}{lcccc}
\hline Dependent variable & $\begin{array}{c}\text { Satisfaction } \\
\text { with pay }\end{array}$ & $\begin{array}{c}\text { Satisfaction } \\
\text { with job } \\
\text { security }\end{array}$ & $\begin{array}{c}\text { Satisfaction } \\
\text { with work } \\
\text { itself }\end{array}$ & $\begin{array}{c}\text { Satisfaction } \\
\text { with hours } \\
\text { worked }\end{array}$ \\
\hline Union coverage 4 years hence & 0.033 & 0.161 & -0.076 & 0.053 \\
Union coverage 3 years hence & {$[0.092]$} & {$[0.090]^{+}$} & {$[0.080]$} & {$[0.086]$} \\
Union coverage 2 years hence & 0.002 & 0.139 & 0.075 & 0.119 \\
& {$[0.076]$} & {$[0.074]^{*}$} & {$[0.067]$} & {$[0.072]^{+}$} \\
Union coverage within the next year & -0.063 & -0.103 & -0.109 & -0.013 \\
& {$[0.063]$} & {$[0.061]^{+}$} & {$[0.055]^{*}$} & {$[0.059]$} \\
Union coverage 0-1 year & -0.105 & -0.167 & -0.099 & -0.034 \\
& $0.052]^{*}$ & {$[0.050]^{* *}$} & {$[0.045]^{*}$} & {$[0.049]$} \\
Union coverage 1-2 years & 0.054 & -0.169 & -0.042 & 0.041 \\
& {$[0.044]$} & {$[0.043]^{* *}$} & {$[0.038]$} & {$[0.041]$} \\
Union coverage 2-3 years & 0.030 & -0.166 & -0.124 & 0.062 \\
Union coverage 3 years or more & {$[0.052]$} & {$[0.051]^{* *}$} & {$[0.045]^{* *}$} & {$[0.049]$} \\
& 0.002 & -0.210 & -0.149 & 0.012 \\
& {$[0.059]$} & {$[0.058]^{* *}$} & {$[0.052]^{* *}$} & {$[0.056]$} \\
[Coeff.] Union coverage 0-1 year - & -0.074 & -0.234 & -0.187 & -0.047 \\
[Coeff.] Union coverage within the & {$[0.051]$} & {$[0.050]^{* *}$} & {$[0.045]^{* *}$} & {$[0.048]$} \\
next year = & 0.159 & -0.002 & 0.056 & 0.075 \\
& {$[0.047]^{* *}$} & {$[0.046]$} & {$[0.041]$} & {$[0.044]+$} \\
\hline
\end{tabular}

3b: Women

\begin{tabular}{lcccc}
\hline Dependent variable & $\begin{array}{c}\text { Satisfaction } \\
\text { with pay }\end{array}$ & $\begin{array}{c}\text { Satisfaction } \\
\text { with job } \\
\text { security }\end{array}$ & $\begin{array}{c}\text { Satisfaction } \\
\text { with work } \\
\text { itself }\end{array}$ & $\begin{array}{c}\text { Satisfaction } \\
\text { with hours } \\
\text { worked }\end{array}$ \\
\hline Union coverage 4 years hence & -0.082 & 0.027 & -0.025 & 0.163 \\
Union coverage 3 years hence & {$[0.106]$} & {$[0.099]$} & {$[0.094]$} & {$[0.097]+$} \\
Union coverage 2 years hence & -0.052 & -0.141 & -0.079 & 0.043 \\
& {$[0.093]$} & {$[0.086]$} & {$[0.082]$} & {$[0.085]$} \\
Union coverage within the next year & -0.066 & -0.013 & -0.033 & -0.015 \\
& {$[0.078]$} & {$[0.072]$} & {$[0.068]$} & {$[0.071]$} \\
Union coverage 0 -1 year & -0.187 & -0.189 & -0.232 & -0.066 \\
& $0.064]^{* *}$ & {$[0.059]^{* *}$} & {$[0.056]^{* *}$} & {$[0.058]$} \\
Union coverage 1-2 years & 0.035 & -0.087 & -0.106 & 0.018 \\
& {$[0.056]$} & {$[0.052]^{+}$} & {$[0.049]^{*}$} & {$[0.051]$} \\
Union coverage 2-3 years & 0.010 & -0.161 & -0.179 & -0.025 \\
& {$[0.067]$} & {$[0.062]^{* *}$} & {$[0.059]^{* *}$} & {$[0.061]$} \\
Union coverage 3 years or more & 0.058 & -0.183 & -0.174 & -0.069 \\
& {$[0.077]$} & {$[0.071]^{* *}$} & {$[0.067]^{* *}$} & {$[0.070]$} \\
\hline [Coeff.] Union coverage $0-1$ year - & -0.038 & -0.193 & -0.223 & -0.016 \\
& {$[0.068]$} & {$[0.063]^{* *}$} & {$[0.060]^{* *}$} & {$[0.062]$} \\
\hline
\end{tabular}


[Coeff.] Union coverage within the next year $=$

$[0.059]^{* *} \quad[0.055]+\quad[0.052]^{*} \quad[0.054]$

Note: + sig. at $10 \%,{ }^{*}$ sig. at $5 \%$, ${ }^{* *}$ sig. at $1 \%$. Standard errors are in parentheses. Same control variables and number of observations as Table 2. 
Table 4: Fixed effects job satisfaction regressions: Leads to and lags of union coverage by membership status

\begin{tabular}{|c|c|c|}
\hline Dependent variable: Overall job satisfaction & Men & Women \\
\hline \multirow{3}{*}{$\begin{array}{l}\text { Union member, i.e. the sum of } \beta+\theta+\lambda \text { parameters } \\
\text { Union coverage } 4 \text { years hence } \& \text { become member in the } 1^{\text {st }} \\
\text { year }\end{array}$} & & \\
\hline & -0.194 & -0.221 \\
\hline & {$[0.156]$} & {$[0.177]$} \\
\hline \multirow{2}{*}{$\begin{array}{l}\text { Union coverage } 3 \text { years hence } \& \text { become member in the } 1^{\text {st }} \\
\text { year }\end{array}$} & 0.009 & -0.064 \\
\hline & [0.119] & [0.154] \\
\hline \multirow{2}{*}{$\begin{array}{l}\text { Union coverage } 2 \text { years hence } \& \text { become member in the } 1^{\text {st }} \\
\text { year }\end{array}$} & -0.129 & -0.015 \\
\hline & [0.098] & {$[0.123]$} \\
\hline \multirow{2}{*}{$\begin{array}{l}\text { Union coverage within the next year \& become member in } \\
\text { the } 1^{\text {st }} \text { year }\end{array}$} & -0.243 & -0.494 \\
\hline & {$[0.077]^{* *}$} & $\begin{array}{c}{[0.095]^{*}} \\
*\end{array}$ \\
\hline \multirow[t]{2}{*}{ Union coverage union $0-1$ year \& member $0-1$ year } & -0.075 & -0.297 \\
\hline & [0.057] & $\begin{array}{c}{[0.074]^{*}} \\
*\end{array}$ \\
\hline \multirow[t]{2}{*}{ Union coverage $1-2$ years $\&$ member $1-2$ years } & -0.099 & -0.375 \\
\hline & [0.064] & $\begin{array}{c}{[0.087]^{*}} \\
*\end{array}$ \\
\hline \multirow[t]{2}{*}{ Union coverage $2-3$ years $\&$ member $2-3$ years } & -0.147 & -0.393 \\
\hline & {$[0.071]^{*}$} & $\begin{array}{c}{[0.098]^{*}} \\
*\end{array}$ \\
\hline \multirow[t]{2}{*}{ Union coverage 3 years or more \& member 3 years or more } & -0.312 & -0.384 \\
\hline & {$[0.059]^{* *}$} & $\begin{array}{c}{[0.081]^{*}} \\
*\end{array}$ \\
\hline \multirow{2}{*}{$\begin{array}{l}\text { [Coeff.] Union coverage } 0-1 \text { year }- \text { [Coeff.] Union } \\
\text { coverage within the next year }=\end{array}$} & 0.168 & 0.197 \\
\hline & {$[0.074]^{*}$} & {$[0.093]^{*}$} \\
\hline \multicolumn{3}{|l|}{ Non-member, i.e. $\beta$ parameter } \\
\hline Union coverage 4 years hence $\&$ remain non-member & $\begin{array}{c}0.152 \\
{[0.091]+}\end{array}$ & $\begin{array}{c}0.013 \\
{[0.104]}\end{array}$ \\
\hline Union coverage 3 years hence $\&$ remain non-member & $\begin{array}{c}0.155 \\
{[0.079]^{*}}\end{array}$ & $\begin{array}{c}-0.126 \\
{[0.094]}\end{array}$ \\
\hline Union coverage 2 years hence $\&$ remain non-member & $\begin{array}{c}-0.064 \\
{[0.065]}\end{array}$ & $\begin{array}{c}-0.017 \\
{[0.080]}\end{array}$ \\
\hline $\begin{array}{l}\text { Union coverage within the next year \& remain non- } \\
\text { member }\end{array}$ & -0.055 & $\begin{array}{c}-0.260 \\
{[0.065]^{*}} \\
*\end{array}$ \\
\hline Union coverage union $0-1$ year \& non-member & $\begin{array}{c}0.032 \\
{[0.046]}\end{array}$ & $\begin{array}{c}-0.064 \\
{[0.057]}\end{array}$ \\
\hline Union coverage $1-2$ years \& non-member & $\begin{array}{c}-0.137 \\
{[0.062]^{*}}\end{array}$ & $\begin{array}{c}-0.088 \\
{[0.077]}\end{array}$ \\
\hline Union coverage 2-3 years \& non-member & -0.078 & -0.077 \\
\hline
\end{tabular}




\begin{tabular}{lcc} 
Union coverage 3 years or more \& non-member & $\begin{array}{c}0.080] \\
-0.110\end{array}$ & $\begin{array}{c}0.094] \\
-0.310 \\
{[0.075]^{*}} \\
*\end{array}$ \\
\hline $\begin{array}{l}\text { [Coeff.] Union coverage 0-1 year - [Coeff.] Union } \\
\text { coverage within the next year }=\end{array}$ & 0.086 & 0.196 \\
& {$[0.052]+$} & $\begin{array}{c}0.066]^{*} \\
*\end{array}$ \\
\hline
\end{tabular}

Note: + sig. at $10 \%, *$ sig. at $5 \%, * *$ sig. at $1 \%$. Standard errors are in parentheses. Same control variables and number of observations as Table 2. 
Table A1: Some Descriptive Statistics, BHPS 1995-2005

\begin{tabular}{|c|c|c|c|c|c|c|}
\hline & \multicolumn{3}{|c|}{ Men } & \multicolumn{3}{|c|}{ Women } \\
\hline & \multicolumn{2}{|c|}{ Union-covered } & \multirow{2}{*}{$\begin{array}{c}\text { Non- } \\
\text { unionize } \\
\mathrm{d} \text { firms }\end{array}$} & \multicolumn{2}{|c|}{ Union-covered } & \multirow{2}{*}{$\begin{array}{c}\text { Non- } \\
\text { unionize } \\
\text { d firms }\end{array}$} \\
\hline & $\begin{array}{l}\text { Union } \\
\text { member }\end{array}$ & $\begin{array}{c}\text { Non- } \\
\text { members }\end{array}$ & & $\begin{array}{l}\text { Union } \\
\text { member }\end{array}$ & $\begin{array}{c}\text { Non- } \\
\text { members }\end{array}$ & \\
\hline \multirow{2}{*}{ Overall job satisfaction } & 5.07 & 5.21 & 5.27 & 5.28 & 5.38 & 5.50 \\
\hline & $(1.35)$ & $(1.27)$ & $(1.29)$ & $(1.34)$ & $(1.26)$ & $(1.29)$ \\
\hline \multirow{2}{*}{ Job satisfaction: total pay } & 4.77 & 4.85 & 4.81 & 4.97 & 4.95 & 4.90 \\
\hline & $(1.49)$ & $(1.49)$ & $(1.55)$ & $(1.51)$ & $(1.46)$ & $(1.61)$ \\
\hline \multirow{2}{*}{ Job satisfaction: security } & 5.02 & 5.20 & 5.37 & 5.23 & 5.43 & 5.64 \\
\hline & $(1.59)$ & $(1.49)$ & $(1.47)$ & $(1.55)$ & $(1.45)$ & $(1.39)$ \\
\hline \multirow{2}{*}{ Job satisfaction: work itself } & 5.18 & 5.27 & 5.44 & 5.28 & 5.32 & 5.54 \\
\hline & $(1.41)$ & $(1.33)$ & $(1.30)$ & $(1.39)$ & $(1.37)$ & $(1.31)$ \\
\hline \multirow{2}{*}{$\begin{array}{l}\text { Job satisfaction: hours } \\
\text { worked }\end{array}$} & 4.96 & 5.10 & 4.99 & 5.28 & 5.37 & 5.38 \\
\hline & $(1.44)$ & $(1.36)$ & $(1.46)$ & $(1.40)$ & $(1.32)$ & $(1.40)$ \\
\hline \multirow{2}{*}{ Age } & 40.31 & 36.16 & 36.88 & 38.69 & 34.55 & 37.08 \\
\hline & $(10.04)$ & $(12.32)$ & $(11.95)$ & $(10.90)$ & $(11.24)$ & $(12.05)$ \\
\hline \multirow{2}{*}{ Married } & 0.64 & 0.53 & 0.54 & 0.63 & 0.50 & 0.51 \\
\hline & $(0.47)$ & $(0.49)$ & $(0.49)$ & $(0.48)$ & $(0.49)$ & $(0.49)$ \\
\hline \multirow{2}{*}{$\begin{array}{l}\text { Ln(annual individual } \\
\text { income) }\end{array}$} & 9.83 & 9.64 & 9.67 & 9.28 & 9.13 & 9.08 \\
\hline & $(0.49)$ & $(0.74)$ & $(0.77)$ & $(0.64)$ & $(0.80)$ & $(0.81)$ \\
\hline \multirow{2}{*}{ Ln(work hours) } & 3.65 & 3.64 & 3.67 & 3.39 & 3.34 & 3.31 \\
\hline & $(0.15)$ & $(0.22)$ & $(0.23)$ & $(0.35)$ & $(0.43)$ & $(0.50)$ \\
\hline \multirow{2}{*}{ Completed first degree } & 0.07 & 0.12 & 0.12 & 0.06 & 0.09 & 0.08 \\
\hline & $(0.25)$ & $(0.32)$ & $(0.33)$ & $(0.25)$ & $(0.28)$ & $(0.27)$ \\
\hline \multirow{2}{*}{ Completed higher degree } & 0.01 & 0.03 & 0.03 & 0.01 & 0.01 & 0.01 \\
\hline & $(0.13)$ & $(0.17)$ & $(0.17)$ & $(0.10)$ & $(0.12)$ & $(0.10)$ \\
\hline \multirow{2}{*}{ Temporary job } & 0.02 & 0.06 & 0.04 & 0.02 & 0.06 & 0.05 \\
\hline & $(0.14)$ & $(0.24)$ & $(0.26)$ & $(0.15)$ & $(0.23)$ & $(0.21)$ \\
\hline \multirow{2}{*}{ Promotional opportunity } & 0.58 & 0.61 & 0.42 & 0.60 & 0.61 & 0.35 \\
\hline & $(0.49)$ & $(0.48)$ & $(0.49)$ & $(0.49)$ & $(0.49)$ & $(0.47)$ \\
\hline \multirow{2}{*}{ Work size: $1-24$} & 0.13 & 0.17 & 0.43 & 0.21 & 0.20 & 0.53 \\
\hline & $(0.34)$ & $(0.39)$ & $(0.49)$ & $(0.41)$ & $(0.39)$ & $(0.49)$ \\
\hline \multirow{2}{*}{ Work size: $25-199$} & 0.70 & 0.69 & 0.52 & 0.67 & 0.66 & 0.44 \\
\hline & $(0.46)$ & $(0.47)$ & $(.50)$ & $(0.47)$ & $(0.47)$ & $(0.49)$ \\
\hline \multirow{2}{*}{ Health: very good } & 0.27 & 0.28 & 0.29 & 0.22 & 0.24 & 0.24 \\
\hline & $(0.45)$ & $(0.45)$ & $(0.45)$ & $(0.41)$ & $(0.43)$ & $(0.43)$ \\
\hline
\end{tabular}


Table A2: Number of leads and lags to working in a union-covered firm,

\section{BHPS (1995-2005)}

A) Leads

\begin{tabular}{|c|c|c|c|c|c|c|}
\hline \multirow[b]{2}{*}{ Leads } & \multicolumn{3}{|c|}{ Male workers } & \multicolumn{3}{|c|}{ Female workers } \\
\hline & Total & $\begin{array}{l}\text { Will join } \\
\text { union in } \\
\text { the } 1^{\text {st }} \text { year }\end{array}$ & $\begin{array}{l}\text { Will not } \\
\text { join union } \\
\text { in the } 1^{\text {st }} \\
\text { year }\end{array}$ & Total & $\begin{array}{l}\text { Will join } \\
\text { union in } \\
\text { the } 1^{\text {st }} \text { year }\end{array}$ & $\begin{array}{l}\text { Will not } \\
\text { join union } \\
\text { in the } 1^{\text {st }} \\
\text { year }\end{array}$ \\
\hline $\begin{array}{l}\text { Union coverage } 4 \text { years } \\
\text { hence }\end{array}$ & 234 & 57 & 177 & 202 & 50 & 152 \\
\hline $\begin{array}{l}\text { Union coverage } 3 \text { years } \\
\text { hence }\end{array}$ & 374 & 110 & 251 & 290 & 69 & 202 \\
\hline $\begin{array}{l}\text { Union coverage } 2 \text { years } \\
\text { hence }\end{array}$ & 633 & 181 & 410 & 486 & 127 & 307 \\
\hline $\begin{array}{l}\text { Union coverage within the } \\
\text { next year }\end{array}$ & 1,203 & 343 & 772 & 971 & 273 & 577 \\
\hline
\end{tabular}

B) Lags

\begin{tabular}{|c|c|c|c|c|c|c|}
\hline Lags (Male workers) & Total & $\begin{array}{l}\text { Covered } \\
\text { non- } \\
\text { members }\end{array}$ & $\begin{array}{c}\text { Member } \\
\text { for } 0-1 \\
\text { year }\end{array}$ & $\begin{array}{c}\text { Member } \\
\text { for 1-2 } \\
\text { years }\end{array}$ & $\begin{array}{c}\text { Member } \\
\text { for } 2-3 \\
\text { years }\end{array}$ & $\begin{array}{c}\text { Member } \\
\text { for } 3 \\
\text { years or } \\
\text { more }\end{array}$ \\
\hline Union coverage $0-1$ year & 2,706 & 1,318 & 1,198 & - & - & - \\
\hline Union coverage $1-2$ years & 1,478 & 502 & 108 & 773 & - & - \\
\hline Union coverage $2-3$ years & 950 & 264 & 47 & 50 & 543 & - \\
\hline $\begin{array}{l}\text { Union coverage } 3 \text { years or } \\
\text { more }\end{array}$ & 3,348 & 795 & 79 & 78 & 80 & 2,204 \\
\hline Lags (Female workers) & Total & $\begin{array}{l}\text { Covered } \\
\text { non- } \\
\text { members }\end{array}$ & $\begin{array}{c}\text { Member } \\
\text { for } 0-1 \\
\text { year }\end{array}$ & $\begin{array}{c}\text { Member } \\
\text { for } 1-2 \\
\text { years }\end{array}$ & $\begin{array}{c}\text { Member } \\
\text { for } 2-3 \\
\text { years }\end{array}$ & $\begin{array}{c}\text { Member } \\
\text { for } 3 \\
\text { years or } \\
\text { more }\end{array}$ \\
\hline Union coverage $0-1$ year & 1,843 & 967 & 687 & - & - & - \\
\hline Union coverage $1-2$ years & 957 & 372 & 92 & 390 & - & - \\
\hline Union coverage $2-3$ years & 613 & 213 & 41 & 44 & 258 & - \\
\hline $\begin{array}{l}\text { Union coverage } 3 \text { years or } \\
\text { more }\end{array}$ & 1,873 & 607 & 83 & 59 & 79 & 940 \\
\hline
\end{tabular}

